\title{
Observations and Lessons from Election Administration in Nigeria
}

\author{
Tyler St. Clair and Shaniqua Williams
}

Abstract The consolidation of democracy in transitioning governments is a topic of interest for established nations around the globe. As Auburn University graduate students who have focused on election administration in the United States, we found that the opportunity to observe elections in a comparative perspective created a unique learning experience. In February 2019, Nigeria was preparing to host their sixth democratic election since the end of military rule in 1999. Although these elections were expected to be the next step in launching the country forward as an exemplar of democracy, they were instead delayed at the last minute due to logistical issues. The response from the electorate was immediate: institutions and the electoral process were questioned and officials were criticized. Our in-country observations illustrate the true costs of postponing the presidential election and the impact that the decision to postpone the election had on the democratic process in Nigeria.

Keywords Elections $\bullet$ Nigeria $\bullet$ INEC $\bullet$ YIAGA $\bullet$ Auburn

- Comparative $\bullet$ Corruption $\bullet$ Administration $\bullet$ Democracy $\bullet$ Observers

T. St. Clair $(\bowtie) \bullet S$. Williams

Auburn University, Auburn, AL, USA

e-mail: tks0009@tigermail.auburn.edu

(C) The Author(s) 2019

M. Brown et al. (eds.), The Future of Election Administration, Elections, Voting, Technology, https://doi.org/10.1007/978-3-030-18541-1_18 
As graduate students in the Master of Public Administration (MPA) program and doctoral program in Public Administration and Policy in the Political Science department at Auburn University, we have become intimately involved in studying election administration. As Auburn is home to the largest election administration faculty in the nation, it is only natural for students to be encouraged to pursue studies in this area. Up until this point in our work, we had focused solely on elections in the context of the United States and had not studied elections in the international context.

The offering of a comparative elections course in the spring of 2019 was an interesting change in the scope of our research. When we were offered the opportunity to travel to Abuja, Nigeria, as election observers, we saw the opportunity to gain a new comparative perspective to use when considering our course assignments and readings. This trip allowed us to compare our knowledge of the electoral process in an established democracy with the electoral process in a country that is experiencing democratic consolidation. What challenges does this present to us as students, especially when we consider Nigeria and its history, and the implications of this election cycle? Comparing our conventional knowledge with a transitioning democracy serves as the basis of our case study.

Unlike in the United States, the voting and registration process in Nigeria is centralized. The agency responsible for voter registration and voting is the Independent Nigerian Electoral Commission (INEC). INEC comprises 13 officials who are appointed by the President.

In order to be accredited as election observers, we partnered with Youth Initiative for Advocacy, Growth and Advancement (YIAGA), a Nigerian-based non-governmental organization. YIAGA has chapters across Africa and mobilizes citizens in the form of a data-gathering campaign to observe polling place practices. We worked closely under Samson Itodo, Executive Director, and Cynthia Mbamalu, Program Manager. YIAGA utilizes the Parallel Vote Tabulation (PVT) methodology to observe and gather data from election day observations. This method consists of a detailed text message code that deployed observers use to report back to the data center in real time. While we were able to participate in a pre-election data simulation exercise and visit several INEC offices in the local government areas surrounding the Federal Central Territory in Abuja for pre-election observation, we were not able to experience the PVT process in practice due to the decision made by the INEC to postpone the election by a week. Although we did not observe on Election Day, we were able to better understand election administration in Nigeria by attending 
the YIAGA and Situation Room press conference, the International Briefing for Accredited Observers (Domestic and Foreign) for the 2019 General Election, and by witnessing current president Muhammadu Buhari and former vice president Atiku Abubakar sign the National Peace Accord in which both candidates agreed to ensure that their followers will respect the peaceful transition of power. Over the course of our week in Abuja we experienced and observed a number of events designed to provide observers with critical information for the upcoming elections. However, it was not until the final day of our trip that we began to truly understand the administrative environment in which the elections in Nigeria were being conducted.

To begin, we should start at the end. Once it was announced in the early morning hours of Saturday, February 16, Election Day, that the Independent National Electoral Commission (INEC) was postponing the election, we had a meeting with Samson Itodo, Executive Director of YIAGA, as well as members of his team for a final debriefing. As we went around the room discussing what we found most interesting, Samson made the comment that "Nigeria [through its election administration processes and procedures] is paying the price for the cost of corruption."

How do we define the administrative cost or burden of corruption? First, Nigeria still relies on fingerprinting ballots and manually counting them one by one. Second, only one voter is permitted in the polling unit at any given time during Election Day. According to INEC, the average time for a voter to cast their ballot lies somewhere between two and five minutes. Nigeria has over 84 million registered voters. ${ }^{1}$ If a polling unit has 500 registered voters at 2 minutes each, that would take roughly 1000 minutes, upwards of 16 hours for all voters to participate. In a day where voting only occurs between $8 \mathrm{AM}$ and $2 \mathrm{PM}$, the time allotted is not adequate to address the time needed. In this process which is designed to promote security, time becomes a significant cost for the average voter, whether it be in travel or time spent waiting to cast a ballot.

From our conversations with stakeholders, we learned that Nigerian governance has a long history of corruption and intimidation, and Nigerians are uniquely sensitive to the impact that unseen forces can have on the political direction of their country. Past corruption breeds future suspicion and the lack of transparency from the Independent National Electoral Commission leading up to the postponement of the February

\footnotetext{
${ }^{1}$ Independent National Electoral Commission. 2019. https://www.inecnigeria.org.
} 
16th presidential election led to unsurprising backlash from Nigerian citizens. What was supposed to be seen, and could still be seen, as the next major step forward for Nigeria in establishing itself as an exemplar of democracy in Africa has, for the moment, sown distrust and anger among the electorate.

While INEC operated under the guise of efficiency, they over-estimated their capacity to address the logistics of administering the election.

Nigeria has the largest population on the continent, which presents a number of challenges-how do officials access remote areas where paved roads do not exist? Can they airlift materials, or will they be transported by truck? As Nigeria does not have absentee voting, many citizens must travel back to their home state to vote-for many in Nigeria, this is no small task and requires a significant investment of time and resources to accomplish. Nigeria's population consists of 190 million individuals. There were 72 presidential candidates alone in the election cycle, the most ever for presidential election in Nigeria. There were thousands of security forces being deployed on Election Day-4030 non-security personnel and 8000 special protection personnel. ${ }^{2}$ The total estimated cost of the election itself hovers around 198 billion US dollars, which equates to 6.5 US dollars per voter. ${ }^{3}$

With such a large population, the number of places to vote must also be large. In Nigeria, there are 119,973 polling units across the country; in areas where the population exceeds the maximum number of voters per unit (voting units should have no more than 750 registered voters), there are multiple voting points, $57,073 .{ }^{4}$ These are spread between urban and rural areas, with varying degrees of difficulty in access. Transportation of materials, both sensitive and non-sensitive, can be difficult. ${ }^{5}$ For example, in remote areas that do not have quality infrastructure, airlifting materials in for election day is an optimal means of transportation. ${ }^{6}$

\footnotetext{
${ }^{2}$ Mohammed Adamu. Inspector General of Police. INEC briefing. February 12, 2019.

${ }^{3}$ Antonia Okoosi-Simbine. National Commission. INEC budget, INEC briefing. February $12,2019$.

${ }^{4}$ INEC briefing. February 12, 2019.

${ }^{5}$ INEC distinguishes between sensitive and non-sensitive election materials. Sensitive materials include ballot papers, smart card readers, and results sheets, while non-sensitive materials include everything else.

${ }^{6}$ According to INEC this was not feasible, and materials were instead loaded on to trucks for transportation, delaying delivery and further slowing the process.
} 
As in many African countries, security concerns remain a constant problem. In Kano State, ballot papers were intercepted and taken; a state governor's convoy was attacked by a faction of Boko Haram. ${ }^{7}$ INEC offices were firebombed and the materials inside destroyed. In Anambra State two containers of sensitive materials including smart card readers were also destroyed. ${ }^{8}$

Even after numerous INEC offices were attacked and materials burned, smart card readers destroyed, and so on, INEC continued to reinforce the message that they were prepared to conduct the election.

When discussing the election, the overarching concern regarding the Nigerian election was safety and security. Nigerian officials from the government and political parties both called for peace and calm during the process. Foreign dignitaries seemed intent on reinforcing the message that Nigerians should take this election as an opportunity to show the world that they too were capable of conducting an election unmarred by violence and intimidation, one that would give each citizen the chance to cast their ballot without interference. At a YIAGA press briefing the day before election day, US Ambassador Symington stated, "We have for weeks talked about free, transparent, and now let's stress peaceful elections. For that is the essential task ... The peace and security of the vote tomorrow is the job of every Nigerian. Every single one." This sentiment was echoed by fellow ambassadors and leaders of International Non-Governmental Organizations ( INGOs) throughout the briefing.

What we failed to see, and what ultimately seemed to be of greatest consequence, was not the security of the election but instead the ability to actually administer the process to Nigerian voters around the country. While security concerns were warranted, they were not believed to be of greatest impact in the decision to postpone the election by INEC. Their decision to postpone due to logistical concerns related to the delivery of sensitive and non-sensitive election materials suggests a different calculation of cost for the 2019 presidential election.

The true costs lie somewhere between the tangible inputs and lack of an outcome satisfactory to the citizenry at large. INGOs and civil society organizations poured time, money, and manpower into mobilizing

\footnotetext{
${ }^{7}$ Ruth Maclean and Eromo Egbejule. "Nigeria postpones election just hours before polls due to open." The Guardian. February 15 2019. https://www.theguardian.com/ world $/ 2019 / \mathrm{feb} / 16 /$ nigeria-postpones-election-just-hours-before-polls-due-to-open.

${ }^{8}$ Akoh Godday. "INEC confirms destruction of smart card readers." Naija News. February 12, 2019. https://www.naijanews.com/2019/02/12/inec-confirms-destruction-of-smartcard-readers-as-fire-guts-office/.
} 
citizens, promoting transparency, and encouraging every Nigerian to get out and vote. The Youth Corp was mobilized to polling units and points around the country as part of their civic duty to their nation. ${ }^{9}$ Materials were transported to various INEC offices with the intent of being used. The lack of outcome came when, despite the multitude of inputs utilized in preparing for Election Day, the Nigerian electorate were unable to exercise their right to the democratic process and cast their ballot for the leader of their choosing. The ultimate cost is the loss of confidence Nigerians place in their government institutions that exist to protect their ability to participate in self-government and construct a future that is uniquely and genuinely Nigerian.

One of the themes noticed throughout the week was that, while Nigerians were optimistic for a successful election this cycle, they were cautiously so. Democracy doesn't develop overnight, and even the most developed of countries has administrative growing pains from time to time. Nigeria is a relatively young independent country, and because of their youth the progress they have made should be commended. However, Nigeria must continue to move forward with each election, inch by inch, to assume the leading role in Africa that many believe they can fill. As was said by many foreign observers and diplomats, where Nigeria goes, so goes the rest of Africa - and while Nigeria may still be paying for its past, it is certainly making strides toward a brighter future. ${ }^{10}$

\footnotetext{
${ }^{9}$ The National Youth Service Corp in Nigeria is a national service program geared to promote pride of country and service to their fellow Nigerians. http://www.nysc.gov.ng/ aboutscheme.html.

${ }^{10}$ The Nigerian election took place on Saturday, February 23, 2019, one week after the original scheduled election date.
} 
Open Access This chapter is licensed under the terms of the Creative Commons Attribution 4.0 International License (http://creativecommons.org/licenses/ by $/ 4.0 /$ ), which permits use, sharing, adaptation, distribution and reproduction in any medium or format, as long as you give appropriate credit to the original author(s) and the source, provide a link to the Creative Commons licence and indicate if changes were made.

The images or other third party material in this chapter are included in the chapter's Creative Commons licence, unless indicated otherwise in a credit line to the material. If material is not included in the chapter's Creative Commons licence and your intended use is not permitted by statutory regulation or exceeds the permitted use, you will need to obtain permission directly from the copyright holder. 